\title{
ENVIRONMENTAL MANAGEMENT PLANS: A KEY TOOL IN ENSURING SUCCESSFUL LONG-TERM ENVIRONMENTAL MANAGEMENT AT CLOSED MINE SITES WITH ML/ARD
}

\author{
Kim Bellefontaine, M.Sc., P.Geo. ${ }^{1}$ \\ Bill Price, Ph.D., P.Ag. ${ }^{2}$ \\ ${ }^{1}$ British Columbia Ministry of Energy and Mines \\ P.O. Box 9320 Stn Prov Govt \\ Victoria, B.C. V8W 9N3 \\ Kim.Bellefontaine@gems1.gov.bc.ca \\ ${ }^{2}$ Natural Resources Canada, Mine Effluents Program - CANMET \\ 3793 Alfred Avenue, Bag 5000 \\ Smithers, B.C. V0J 2N0 \\ bprice@nrcan.gc.ca
}

\begin{abstract}
Mine sites with metal leaching and acid rock drainage (ML/ARD) or the potential for ML/ARD often require long-term mitigation, monitoring and operator vigilance to ensure environmental protection. One of the biggest challenges to meeting long-term environmental protection goals is retaining the collective corporate, regulatory and community memory of the site conditions, the previous mining activities and the mitigation requirements.
\end{abstract}

There is an increasing need for comprehensive, formalized plans to deal with the long-term management of mine sites with ML/ARD. The establishment of a comprehensive Environmental Management Plan (EMP) can be an extremely important and powerful tool to ensuring long-term environmental protection. The key goal of an EMP is to document key aspects of a mine site that are important to its successful management. An EMP should allow for the tracking of important changes to components of the system, with the purpose of guiding site management and site management decisions. An EMP should also be a living document that is continuously used, improved and updated.

Five key components of an EMP are background data, an assessment of risks, monitoring programs, contingency plans and the resources required to implement contingencies. The specific contents of an EMP will be different for every mine site depending on the ML/ARD mitigation strategies used and the characteristics of the site. The example of a water cover over reactive wastes to minimize ML/ARD is provided to illustrate the types of information required for an EMP.

Several closed mines in British Columbia are in the process of developing EMPs. The Island Copper mine has documented important site information and has undertaken several research projects aimed at assessing risks and reducing the uncertainties associated with a non-traditional treatment system for ML/ARD. A series of manuals have also been developed to address other key aspects of on-going site management.

The development of comprehensive EMPs is clearly in the interests of all stakeholders. These plans will aid mining companies in demonstrating that their mines will continue to be operated in a diligent and effective manner. It also gives comfort to neighbouring communities that environmental protection needs can continue to be met long into the future. 


\section{INTRODUCTION}

Mine sites with metal leaching and acid rock drainage (ML/ARD) or the potential for ML/ARD, often require long-term mitigation, monitoring and operator vigilance to ensure environmental protection. One of the biggest challenges to meeting long-term environmental protection goals is retaining the collective corporate, regulatory and community memory for the mine site. This includes retaining knowledge of factors such as site conditions, the history of mining activities, details of mitigation strategies, and monitoring and maintenance needs (Price, 2002).

During active mining, financial and staffing resources are always higher than during the closure stages of a mine. However, the management of environmental issues such as ML/ARD does not stop at closure. Many key properties and processes that affect ML/ARD continue to be in a state of flux (Price and Bellefontaine, 2002). The effectiveness of ML/ARD mitigation strategies can be very sensitive to changes in biological, geochemical and physical conditions.

Effective long-term environmental protection requires adaptive management strategies. The changing of key mining company staff, consultants, government regulators and community members presents a significant challenge (and potential risk) to effective site management. The key to dealing with this challenge is to maintain the critical base knowledge of a mine site, upon which future important decisions can be made. Oral history cannot be relied upon to ensure successful, long-term management.

This paper presents a regulator's perspective on some of the key challenges in the long-term management of ML/ARD and suggests that comprehensive environmental management plans are critical to ensuring continuing environmental success.

\section{BRITISH COLUMBIA REGULATORY PRINCIPLES}

In British Columbia (BC), mining and exploration activities are regulated in a manner that supports the Province's goals of sustainable resource development, while ensuring reclamation and environmental protection are achieved, and the economic risks, liability and alienation of land and water resources are minimized (British Columbia Ministry of Energy and Mines, 1998a).

Mines are evaluated on a site-specific basis since each possesses a unique geological and environmental setting. The regulatory approach to ML/ARD is heavily weighted towards prevention through prediction 
and design, with an emphasis on ensuring sufficient information is available in a timely manner to make informed decisions (Price and Errington, 1998). In the absence of adequate information, cautious regulatory criteria based on conservative assumptions are applied.

Most ML/ARD mitigation strategies must be designed, constructed and operated in a manner that allows them to perform indefinitely (Price, 1999). Contingency measures are required whenever the uncertainty in prediction or mitigation results in unacceptable environmental risks. In addition, financial security commensurate with ML/ARD liabilities is required. The form of financial security can vary depending on the site and the Permittee. Liabilities include the costs associated with long-term monitoring, maintenance, and collection and treatment of contaminated drainage.

In $\mathrm{BC}$, more than 60 mine sites and advanced exploration sites have the potential to generate sufficient ML/ARD to significantly impact the receiving environment (Figure 1). These sites require on-going mitigation and/or further assessment to determine mitigation requirements due to factors such as the unknown status of the receiving environment or the uncertainties around the evolution of processes that control ML/ARD (Price, 2002). Of the mine sites shown in Figure 1, more than 50 are permanently closed or are on care and maintenance status.

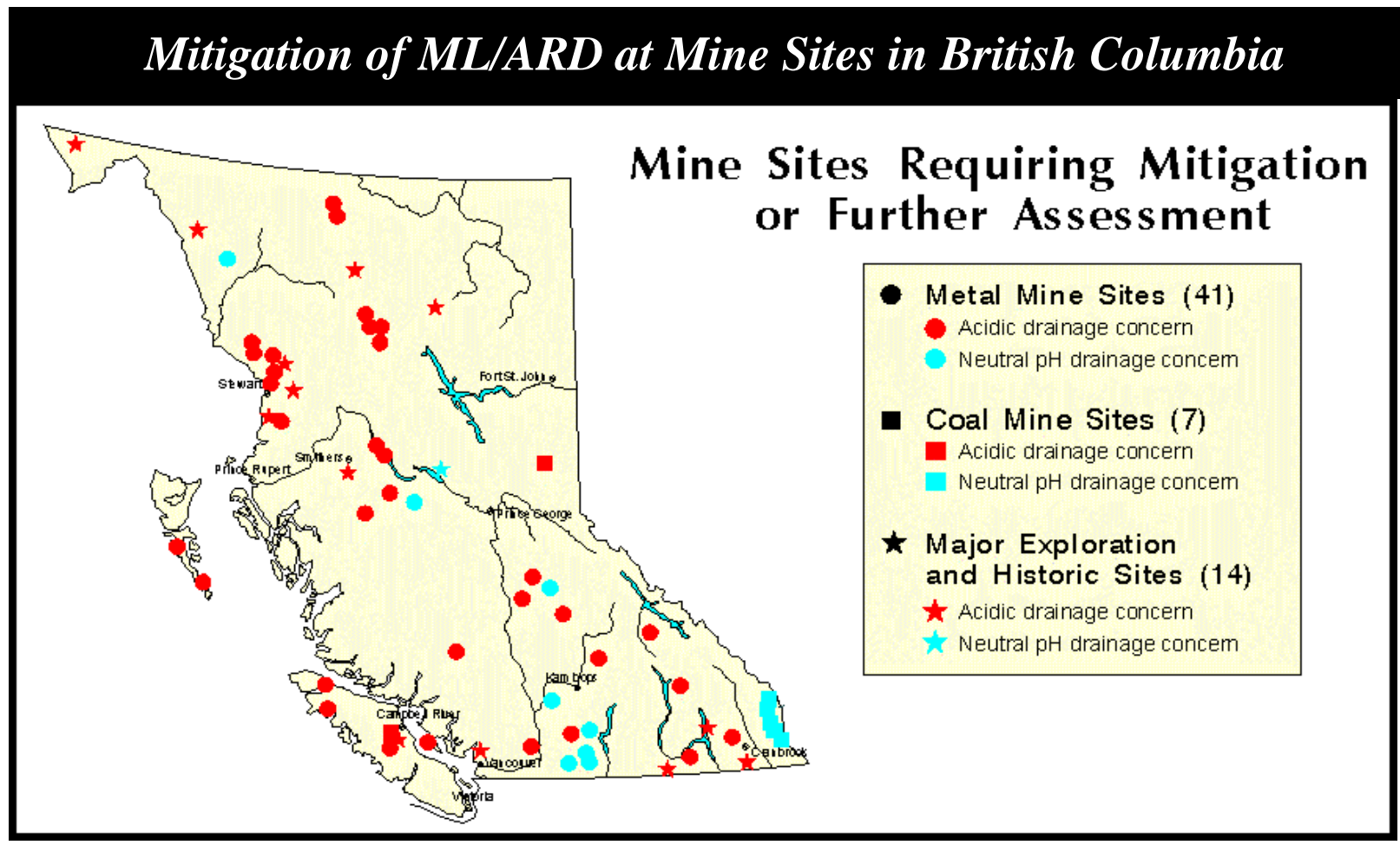

Figure 1: The ML/ARD status of permitted mines and selected exploration and historic mine sites in British Columbia (Price and Bellefontaine, 2002). The number of sites is shown in parenthesis. 


\section{ENVIRONMENTAL MANAGEMENT PLANS}

There is an increasing need for comprehensive, formalized plans to deal with the management of mine sites with ML/ARD or the potential for ML/ARD. Currently, most sites have a mix of internal company documents and/or individual reports and plans undertaken to fulfill specific regulatory requirements. While these documents are inarguably of value, they often deal with a single component of mitigation or a specific issue at a mine site, and not a holistic view of mine site issues and their management. The authors advocate that the establishment of a comprehensive Environmental Management Plan (EMP) can be an extremely important and powerful tool to ensuring long-term environmental protection.

The key goal of an EMP is to document crucial aspects of a mine site that are important to its successful management. It should also allow for the tracking of important changes to components of the system, with the purpose of guiding site management and site management decisions. An EMP should be a living document (or a series of documents) that is continuously used, improved and updated. Ideally, it should allow someone who is qualified, yet unfamiliar with the site, to take over and continue to successfully implement the closure management program.

\section{Components of an Environmental Management Plan}

The contents of an EMP will depend on factors such as the ML/ARD mitigation strategies and the characteristics of the site, and will therefore be different for every mine site. Five key components of an EMP are background data, an assessment of risks and uncertainties, monitoring programs, contingency plans, and resources required to carry out contingencies.

The core ingredient of every EMP should be the information about the mine's history and its environment. Background information such as detailed descriptions of the site, an inventory of materials, their characteristics and disposal locations, and the climatic and hydrological conditions of the site form the backbone of an EMP. Other crucial aspects to include in the background data are the as-built descriptions and design details of mitigation systems and their monitoring and maintenance requirements.

A determination of what other types of information should be included in an EMP should be based on the management requirements, potential limitations and uncertainties of mitigation strategies and possible changes in conditions or processes that could render them less effective. As a start, the following three questions should be asked in relation to each aspect of mitigation or component of the mine site. 
1. What could go wrong and what are the consequences? - (Assessment of Risks)

2. How are potential problems to be detected or performance confirmed? - (Monitoring Program)

3. What corrective actions need to be taken if a problem is detected? - (Contingency Plan)

The answers to these questions will help determine what additional items need to be addressed in an EMP.

\section{Water Cover Example}

To illustrate the types of information required in an EMP, the example of a water cover over reactive wastes to minimize ML/ARD is provided here. Critical background information for this type of mitigation was previously discussed by Price (2001) and includes factors such as the following:

- Waste characteristics - mass, volume, particle size, chemical composition, and ML/ARD potential;

- Disposal site characteristics - storage capacity, discharge requirements, geotechnical conditions, water balance, water quality, rate of flooding and potential re-suspension; and,

- Design of mitigation - which materials require flooding, storage capacity, soluble constituents prior to flooding, extent of flooding, time to flooding, depth of water cover, geotechnical and hydrological aspects of the design.

This information represents the core data that needs to be retained for the site. The three framework questions help to scope the additional requirements for inclusion in an EMP. Table 1 lists some of the potential problems with the use of a water cover, and outlines possible monitoring strategies and potential contingency actions that could be undertaken if a problem was detected.

\section{Potential Components of an Environmental Management Plan for Water Covers as a Mitigation Strategy for MLIARD}




\begin{tabular}{|c|c|c|}
\hline $\begin{array}{l}\text { Changing hydrological } \\
\text { conditions }\end{array}$ & $\begin{array}{l}\text { Site climate data, water balance, } \\
\text { inspections for beaver activity, } \\
\text { additional factors that can change } \\
\text { the hydrology (logging, upstream } \\
\text { water users) }\end{array}$ & $\begin{array}{l}\text { Supplemental water diversions or inputs, increase } \\
\text { depth of water cover, maximize dilution, secondary } \\
\text { storage, drainage treatment, modifications to prevent } \\
\text { beaver activity, removal of beaver }\end{array}$ \\
\hline $\begin{array}{l}\text { Oxidation of surface of wastes } \\
\text { and remobilization of } \\
\text { contaminants }\end{array}$ & $\begin{array}{l}\text { Water quality monitoring of water } \\
\text { column above wastes }\end{array}$ & $\begin{array}{l}\text { Install oxygen consuming or diffusion barrier over } \\
\text { wastes, enhance SRB to promote sulphide } \\
\text { formation, biological adsorption \& assimilation of } \\
\text { contaminants through enhanced primary } \\
\text { productivity }\end{array}$ \\
\hline $\begin{array}{l}\text { Reduction of oxidized surface } \\
\text { layer of wastes and } \\
\text { remobilization of contaminants }\end{array}$ & $\begin{array}{l}\text { Biological monitoring and water } \\
\text { quality monitoring }\end{array}$ & $\begin{array}{l}\text { Increase oxygen influx by directing water through } \\
\text { impoundment, enhance reducing environment to } \\
\text { promote sulphate reduction, other measures to } \\
\text { change redox conditions, barrier to isolate wastes, } \\
\text { drainage treatment }\end{array}$ \\
\hline $\begin{array}{l}\text { Biological uptake of } \\
\text { contaminants }\end{array}$ & $\begin{array}{l}\text { Biological monitoring and water } \\
\text { quality monitoring }\end{array}$ & $\begin{array}{l}\text { Physical barrier to prevent uptake by vegetation and } \\
\text { micro organisms, nets to prevent migratory birds, } \\
\text { prevention strategies for fish migration and spawning }\end{array}$ \\
\hline $\begin{array}{l}\text { Resuspension by waves, ice, } \\
\text { stream flow, and seiching } \\
\text { causing remobilization of } \\
\text { contaminants }\end{array}$ & $\begin{array}{l}\text { Site climate data, depth of water } \\
\text { cover, water quality monitoring }\end{array}$ & $\begin{array}{l}\text { Establish physical barriers to decrease wave action, } \\
\text { increase depth of water cover, install isolation barrier } \\
\text { over wastes }\end{array}$ \\
\hline $\begin{array}{l}\text { Increased contaminant loads } \\
\text { from tailings beach or mine } \\
\text { walls or due to changes in } \\
\text { input drainage chemistry, } \\
\text { process waters, or } \\
\text { destabilization of sludges or } \\
\text { secondary wastes }\end{array}$ & Water quality monitoring & $\begin{array}{l}\text { Isolation barrier for wastes, chemical additions to } \\
\text { water cover, redirect surface flows to decrease } \\
\text { contact with wastes or increase dilution, other forms } \\
\text { of drainage treatment }\end{array}$ \\
\hline
\end{tabular}

Table 1: Examples of potential components of an EMP for a hypothetical mine site that utilizes a water cover over mine wastes to minimize ML/ARD. Modified from Price (2001).

For example, critical issues for reactive wastes stored under a water cover will include their physical and geochemical stability (Price, 2001). The physical stability is largely challenged by hydrological and geotechnical factors. The geochemical stability of the wastes can be affected by many factors including changes in hydrological conditions (e.g. water balance, climate), biological processes (e.g. natural ecological recovery, sedimentation, metal uptake) and physical processes (e.g. resuspension by wind or ice).

Geochemical stability can also be undermined through surface layer oxidation of wastes from an aerated water column. Reducing conditions over an oxidized surface layer can also lead to metal fluxes to the water cover. Changes in water chemistry can result from process water inputs, drainage inputs, inputs from the destabilization of sludges, or increased soluble loadings from exposed tailings beaches or mine walls. 
Monitoring may include items such as climate, water balance, water quality, biological features and visual inspections. Depending on the results, various actions could be warranted. Contingency actions could include modifications to hydrological conditions by diverting or adding input water, or increasing the depth of the water cover to add dilution or isolate wastes from wave action.

Placing an inert barrier over wastes can be effective in preventing oxidative or reductive dissolution processes as well as preventing pathways for biological uptake and avoiding resuspension. Changes to redox conditions can be achieved by adding oxygen to the system or by increasing the quantity of organics to promote reduction. Drainage treatment by conventional lime treatment and/or other methods to achieve contaminant reduction may also be required as a contingency plan.

Other important inclusions for an EMP are contingency plans and the resources needed to implement contingency actions if required. In the water cover example this could include items such as sources of materials, equipment needs, contractors, financial resources etc.

Ideally with thorough planning and forethought of potential issues, as much uncertainty as possible would be removed prior to closure. Items such as an isolating barrier over the wastes or an additional raise of a tailings dam could be prohibitively expensive if not identified and implemented at, or soon after, closure when operational staff and equipment are still present on the site.

\section{Example from British Columbia}

Mines in BC are required to manage ML/ARD issues on their sites for as long as is required to achieve environmental protection. Although there are currently no legislative requirements to formally document and record the critical information needed to ensure successful long-term management, several provincial Ministry documents provide policy, guidance and generic information requirements that are required for a successful EMP (British Columbia Ministry of Energy and Mines, 1998a, 1998b; Price and Errington, 1998).

Several closed mine sites in BC are in the process of developing EMPs, or components of them. The following site is an example of a mine that is developing an EMP to manage a non-traditional ML/ARD treatment system as well as other environmental issues. 


\section{Island Copper Mine}

The Island Copper Mine is a porphyry copper deposit that was mined by open pit methods until 1995. Presently, the main issue at the site is the ML/ARD that originates from on-land waste rock dumps. Water is collected in a series of ditches, and directed to one of two injector points where water is introduced deep within the flooded open pit.

The pit was flooded with seawater, and subsequently rainfall and runoff were directed to the pit lake to create a fresh water cap. This has resulted in a stratified or meromictic lake. The long-term mitigative goal for ML/ARD treatment at the mine was to precipitate metal sulphides under anoxic conditions in the water column. Although this has not yet been achieved, the pit lake is currently acting as a low cost treatment system with different metal removal processes occurring in different layers of the lake.

Studies indicate that regular fertilization of the surface of the pit lake reduces metal concentrations in the surface layer through phytoplankton adsorption and possibly assimilation. In the middle layer of the pit lake, aluminum hydroxide and hydrous ferric oxide precipitation is occurring as well as redox cycling, both of which appear to remove substantial amounts of trace metals from the system. Sulphide precipitation by sulphate reducing bacteria also appears to have been initiated directly at the sedimentwater interface at the bottom of the pit lake.

The mine has been developing an EMP to manage closure issues. The following paragraphs detail some of the base information, key uncertainties, monitoring and contingencies for the pit lake treatment system.

Near the end of mining, important base information was gathered for the site. This included a summary document on the multitude of ML/ARD studies conducted at the mine (Morin and Hutt, 1996). An assessment of drainage chemistry was completed for the on-land waste rock dumps by Morin and Hutt (1994) and a follow-up report on recent trends in drainage chemistry was produced by Pelletier et al. (2001). Other important information on the climate and hydrology of the site was also well documented in various reports.

The key uncertainties with treatment performance of the pit lake are its biogeochemical and physical stability over time. The biological, geochemical and physical processes that occur in the lake are intimately linked. On-going monitoring includes the chemistry of contaminant inputs to the system as well as biological, chemical and physical parameters of the pit lake. 
In addition to regular monitoring, many research projects have been undertaken to address the uncertainties and risks associated with the pit lake treatment system. These include, a fertilization study to determine the biological response and chemical effects of fertilization (Pelletier et al., 2002a), studies to determine biological and sediment oxygen demands (Rescan 1999; Pelletier et al., 2002b), an assessment of pit lake porewater and sediment geochemistry (Pelletier et al., 2002c), dye studies to assess ARD plume dynamics (Muggli et al., 1999), and a remote inspection of injectors to determine the functioning of dispersion/injector systems (Pelletier and Wen, 2001). Other important studies included the modeling of pit lake evolution (Rescan, 2002), the physical stability of the meromictic system (Fisher, 2001), a metal mass balance for the pit lake (Pelletier et al., 2002d) and a biogeochemical model of pit lake metal removal processes (Pelletier et al., 2002e).

An important goal for the Island Copper mine is to have an operational manual that deals with pit lake treatment methods. The innovative approach for treating ML/ARD at Island Copper is supported by provincial regulators. However due to the unproven nature and uncertainties around the technologies proposed, the provincial government has requested the development of measures to improve the current treatment system as well as contingency plans in case the current mitigation strategy proves to be inadequate. These are in the process of being developed. Emergency response plans to some issues are also being drafted.

A series of detailed manuals has been developed to address other on-going site management requirements. The manual dealing with field operations and sampling outlines field sampling methods, station locations, sample preparation and storage, QA/QC procedures, chain of custody forms, procedures for calibration of field equipment, operating procedures for auto-samplers and other stationary equipment devices, data downloading methods, and field procedures for diverting injector flows and for sump and pump operations (Horne, 2002a). Similar detailed levels of information are also included in the manuals covering laboratory methods (Horne, 2002b), laboratory quality (Horne, 2002c), and laboratory procedures (Horne, 2002d).

A very important component of the mitigative works at the site are the ML/ARD collection systems. Given the need for continuing vigilance to ensure functionality, a manual was developed to address ditch inspection and maintenance procedures (Horne, 2002e). Included in this manual are directions for undertaking inspections, areas to be inspected, items to watch for, frequency of inspections, additional triggers for inspections (e.g. heavy rainfall, seismic events), maintenance procedures, resources required 
(e.g. equipment, materials, local contractors, contaminate sediment disposal areas), reporting methods and procedures for follow-up of items identified. Protocols for reporting incidents to regulatory authorities are also included in the manual.

The Island Copper mine is a good example of where the recording of core site information and the ongoing assessment of risks and uncertainties has led to the identification of critical mine site issues and the development of strategies for their on-going monitoring and management. The approach has also been helpful in identifying areas that require more research to resolve uncertainties associated with the mitigation strategies proposed for long-term ML/ARD management.

\section{CONCLUSIONS}

The retention of critical site knowledge is an important component of successful environmental management. Oral history and partial planning cannot be relied upon for environmental protection. Mine sites are not static environments. Physical and ecological processes continue to evolve over time and these processes can seriously impact the effectiveness of ML/ARD mitigations. The dynamic nature of mine sites after closure needs to be fully acknowledged and planned for by the mining industry.

An EMP is a tool that can be utilized to maintain the critical knowledge of a mine site and track important changes in processes that control ML/ARD. An EMP, combined with an adaptive management approach, is key to achieving long-term environmental success.

The development of EMPs is clearly in the interests of all stakeholders. EMPs will aid mining companies in demonstrating that their mines will continue to be operated in a diligent and effective manner. It also gives comfort to neighbouring communities that environmental protection needs can continue to be met long into the future.

\section{REFERENCES}

British Columbia Ministry of Energy and Mines and British Columbia Ministry of Environment, Lands and Parks. 1998a. Policy for metal leaching and acid rock drainage at mine sites in British Columbia. 17 p.

British Columbia Ministry of Energy and Mines. 1998b. Application requirements for a permit approving the mine plan and reclamation program pursuant to the Mines Act. Permit applications document. Approx. 40 p. 
Fisher, T. 2001. Island Copper thermistor project interim report, May 2000. In Reclamation report for 2000 operation and surface work permit no. M-9, Island Copper mine. Approx. 40 p.

Horne, I. 2002a. Island Copper mine, environmental management plan, field operations and sampling manual ICM-02. 154 p.

Horne, I. 2002b. Island Copper mine, environmental management plan, laboratory methods manual ICM03. $113 \mathrm{p}$.

Horne, I. 2002c. Island Copper mine, environmental management plan, quality manual for BCL Biotechnologies Ltd. ICM-04. 109 p.

Horne, I. 2002d. Island Copper mine, environmental management plan, laboratory procedures manual for BCL Biotechnologies Ltd. ICM-05. 103 p.

Horne, I. 2002e. Island Copper mine, environmental management plan, ditch inspection and maintenance manual ICM-01. $80 \mathrm{p}$.

Morin, K.A. and N.M. Hutt. 1994. Prediction of water chemistry form on-land dumps at Island Copper mine, Port Hardy, British Columbia. Approx. 150 p.

Morin, K.A. and N.M. Hutt. 1996. Summary of studies on acidic drainage and metal leaching at Island Copper mine, Port Hardy, British Columbia. 226 p.

Muggli, D.L., G. Poling, M. Wen, and C.A. Pelletier. 1999. Island Copper mine, dye dispersion study of injection plume in pit lake, March 1999. Approx. 90 p.

Pelletier, C.A., R. Mugo, K. Stanfield, and G. Poling. 2001. Island Copper mine, review of mine site drainage chemistry 1997-2000. 108 p.

Pelletier, C.A., and M. Wen. 2001. Island Copper mine, inspection of the pit lake injection systems by remotely operated vehicle, April 18 to 22, 2001. 33 p.

Pelletier, C.A., M. Wen, J. Gerits, D. Muggli, M. McGurk, and T.R. Parsons. 2002a. Island Copper mine, pit lake fertilization study. 223 p.

Pelletier, C.A., M. Wen, S. Granchinho, D. Muggli, and T.R. Parsons. 2002b. Island Copper mine, pit lake oxygen demand study. $53 \mathrm{p}$.

Pelletier, C.A., M. Wen, J. Gerits, S. Granchinho, and K. Telmer. 2002c. Island Copper mine, pit lake porewater and sediment geochemistry. $65 \mathrm{p}$.

Pelletier, C.A., M. Wen, J. Gerits, and M. McGurk. 2002d. Island Copper mine, pit lake metal mass balance. $178 \mathrm{p}$.

Pelletier, C.A., M. Wen, J. Gerits, and K. Telmer. 2002e. Island Copper mine, pit lake biogeochemistry, rates and mechanisms of metal removal. $56 \mathrm{p}$. 
Price, W.A. 1999. Regulation as a tool for reducing the risks associated with metal leaching and acid rock drainage. British Columbia Ministry of Energy and Mines. 29 p.

Price, W.A. 2001. Use of fresh water covers as a mitigation strategy at mine sites in British Columbia. In Proceedings of Eighth BC MEM - MEND Metal Leaching and ARD Workshop, Vancouver, British Columbia, November 28-29. Approx. 24 p.

Price, W.A. 2002. Approaches used in British Columbia to address the challenges posed by metal leaching and acid rock drainage. In Symposium 2002 on Mines and the Environment, Rouyn-Noranda, Quebec, November 3-5. 13 p.

Price, W.A. and K.A. Bellefontaine. 2002. Mitigation of metal leaching and acid rock drainage, in Environmental Trends in British Columbia: 2002. British Columbia Ministry of Water, Land and Air Protection. p 38.

Price, W.A. and J.C. Errington. 1998. Guidelines for metal leaching and acid rock drainage at mine sites in British Columbia. British Columbia Ministry of Energy and Mines. 86 p.

Rescan. 1999. Island Copper mine, summer BOD rate measurements in the pit lake, July 1999. Approx. $27 \mathrm{p}$.

Rescan. 2002. Island Copper mine, pit lake numerical modeling study. 76 p. 